\title{
Interpretation and Construction
}

Randy E. Barnett

Georgetown University Law Center, rb325@law.georgetown.edu

Georgetown Public Law and Legal Theory Research Paper No. 12-034

This paper can be downloaded free of charge from:

https://scholarship.law.georgetown.edu/facpub/820

http://ssrn.com/abstract=2021318

34 Harv. J.L. \& Pub. Pol'y 65-72 (2011)

This open-access article is brought to you by the Georgetown Law Library. Posted with permission of the author. Follow this and additional works at: https://scholarship.law.georgetown.edu/facpub

3 Part of the Constitutional Law Commons 


\title{
INTERPRETATION AND CONSTRUCTION
}

\author{
RANDY E. BARNETT
}

In recent years, it has become apparent that there is a difference between (a) discovering the semantic meaning of the words in the text of the Constitution, and (b) putting that meaning into effect by applying it in particular cases and controversies. To capture this difference, following the lead of political science professor Keith Whittington, legal scholars are increasingly distinguishing between the activities of "interpretation" and "construction."1 Although the Supreme Court unavoidably engages in both activities, it is useful to keep these categories separate. For one thing, if originalism is a theory of interpretation, then it may be of limited utility in formulating a theory of construction, other than in requiring that original meaning not be disregarded or undermined.

In this Essay, I want to elaborate and defend the importance of distinguishing interpretation from construction for the benefit of those who may not be entirely familiar with the distinction between these two activities. Although I begin by offering definitions of interpretation and construction, the labels are not important. Both activities could be called "interpretation" - for example, something like "semantic interpretation" and "applicative interpretation." Still, the terms "interpretation" and "construction" are of ancient vintage and, although not always precisely defined in this way, were traditionally used to distinguish between these two different activities in which courts and other constitutional

\footnotetext{
* Carmack Waterhouse Professor of Legal Theory, Georgetown University Law Center. These remarks were prepared for the Twenty-Ninth Annual Federalist Society National Student Symposium, held at the University of Pennsylvania Law School. Permission to reprint or distribute this Essay for classroom use is hereby granted.

1. See KeITH E. WhitTINGTON, CONSTITUTIONAL INTERPRETATION: TEXTUAL MEANING, ORIGINAL INTENT, AND JUDICIAL REviEW 5-14 (1999); Lawrence B. Solum, Semantic Originalism (Ill. Pub. Law Research Paper No. 07-24, 2008), available at http://ssrn.com/abstract=1120244; see also RANDY E. BARNETT, RESTORING THE LOST CONSTITUTION: THE PRESUMPTION OF LIBERTY 89-120 (2005); JACK BALKIN, FAITH AND FRAMEWORK: HOW WE BUILT OUR CONSTITUTION (forthcoming).
} 
actors routinely engage when dealing with authoritative writings, be they contracts, statutes, or the Constitution.

With this caveat in mind, let us now examine the difference between interpretation and construction. Both interpretation and construction are activities. Interpretation is the activity of identifying the semantic meaning of a particular use of language in context. Construction is the activity of applying that meaning to particular factual circumstances. Originalists may disagree about many things, but they should all agree on the meaningfulness of this distinction. Without it, originalists are very likely to talk past each other, or their critics, and to confuse themselves and others.

What defines originalism as a method of constitutional interpretation is the belief that (a) the semantic meaning of the written Constitution was fixed at the time of its enactment, and that (b) this meaning should be followed by constitutional actors until it is properly changed by a written amendment. ${ }^{2}$ The original meaning of the text provides the law that governs those who govern us; and those who are bound by the Constitution, whether judges or legislators, may not properly change its meaning without going through the amendment process.

It cannot be overstressed that the activity of determining semantic meaning at the time of enactment required by the first proposition is empirical, not normative. ${ }^{3}$ Although we can choose to use words however we wish, as Alice discovered in Wonderland, the social or interpersonal linguistic meaning of words is an empirical fact beyond the will or control of any given speaker (which was the point being made by Alice in Wonderland's author). Although the objective meaning of words sometimes evolves, words have an objective social meaning at any given time that is independent of our opinions of that meaning, and this meaning can typically be discovered by empirical investigation. Conducting such an investigation is no more a normative activity to reach conclusions we like than is discovering what is considered good manners in a given society. Say "please" and "thank you"? Shake hands? Bow to someone of higher social status? Wear a veil? We can approve

2. Cf. Solum, supra note 1 (distinguishing between the (1) the fixation thesis, (2) the clause meaning thesis, (3) the contribution thesis, and (4) the fidelity thesis).

3. Cf. WHITTINGTON, supra note 1 , at 6 . 
or disapprove of such social practices, and decide whether or not to follow them, but their status as norms is a fact.

So too is linguistic usage or semantic meaning. Although I am free to say, "trumetric lyperboly," I cannot expect that anyone but me has access to what these two words mean. As an empirical matter, this phrase simply has no objective meaning in our community of discourse. By the same token, I can make up my own meaning for "automobile" as a time machine, but if I decide to use the word to communicate my thoughts in an English sentence, others will take me to be referring to a car.

Where the semantic meaning of the text provides enough information to resolve a particular issue about constitutionality, applying it will require little, if any, supplementation, and construction will look indistinguishable in practice from interpretation. That each state is entitled to two Senators requires little construction to apply. But however much information is contained in the text of the Constitution, there is not always enough information to resolve a particular issue without something more.

To see why this is so, we must understand how language can be either ambiguous or vague. Ambiguity refers to words that have more than one sense or meaning. Vagueness refers to the penumbra or borderline of a word's meaning, where it may be unclear whether a certain object is included within it or not. Contracts scholar Allan Farnsworth offered this explanation of these two distinct problems of ascertaining linguistic meaning:

Ambiguity, properly defined, is an entirely distinct concept from that of vagueness. A word that may or may not be applicable to marginal objects is vague. But a word may also have two entirely different connotations so that it may be applied to an object and be at the same time both clearly appropriate and inappropriate, as the word "light" may be when applied to dark feathers. Such a word is ambiguous. ${ }^{4}$

In other words, language is ambiguous when it has more than one sense; it is vague when its meaning admits of borderline cases that cannot definitively be ruled in or out of its meaning.

When it comes to resolving ambiguity, the context of a statement usually reveals which sense is meant. For example, the term "arms" in the Second Amendment could be referring to

4. E. Allan Farnsworth, "Meaning" in the Law of Contracts, 76 YALE L.J. 939, 953 (1967). 
weapons or the limbs to which our hands are attached. Context reveals it to refer to weapons. But even when context reveals the intended sense of a potentially ambiguous word, there is still a problem of vagueness. For example, just how much must an object weigh before we cease calling it light and call it heavy? How tall must a person be before he is no longer short?

The problem of ambiguity can usually, though not always, be resolved by originalist interpretive method. Even when we are not entirely certain which of the multiple senses of a word or phrase is the intended meaning, historical evidence almost always establishes one meaning as more probable than the others. ${ }^{5}$ Of course, special problems of potentially irresolvable ambiguity can arise either when the evidence of meaning is lost or nonexistent, or when the drafters deliberately injected ambiguity into the text by using euphemisms-as they did when referring to slavery, a clear word they fastidiously avoided including in the text. ${ }^{6}$ Exceptions aside, evidence of original public meaning generally resolves questions of ambiguity.

In contrast, with vague provisions, the terms themselveseven when interpreted contextually - simply do not contain the information necessary to decide matters of application. What is a "reasonable" search? For that matter, what exactly is a "search"? Is the thermal imaging of a house to detect increased heat caused by marijuana growing in the basement a search?" Because even vague terms have paradigmatic applications lying clearly within the core of their semantic meaning and clearly outside their penumbra, they are not wholly indeterminate. Instead, they are underdeterminate. ${ }^{8}$ Clear cases of items that are light or heavy, of actions that are a search or not a search, exist.

Although most words are potentially vague, we do not face a problem of vagueness until a word needs to be applied to an

5. See Randy E. Barnett, The Misconceived Assumption about Constitutional Assumptions, 103 NW. U. L. REV. 615, 634 (2009).

6. See U.S. CONST. art. I, $\S 2$, cl. 3, amended by U.S. CONST. amend. XIV (referring to slaves as "other Persons"); id. at §9, cl. 1 (referring to slaves as "such Persons" and "each Person"); id. at art. IV, § 2, cl. 3 (referring to slaves as "Person[s] held to Service of Labour").

7. See, e.g., Kyllo v. United States, 533 U.S. 27 (2001) (holding that thermal imaging a house from a public vantage point is a search under the Fourth Amendment).

8. See Lawrence B. Solum, On the Indeterminacy Crisis: Critiquing Critical Dogma, 54 U. CHI. L. REV. 462, 473 (1987) (distinguishing between indeterminacy and underdeterminacy). 
object that may or may not fall within its penumbra. When this happens we must engage in construction. Are restrictions on sound trucks on residential streets an "infringement" on the freedom of speech? ${ }^{9}$ It seems that they could be because someone is being stopped from speaking. Is the requirement of obtaining a parade permit before demonstrating in the public streets an infringement of the freedom of assembly? ${ }^{10}$

The original meaning of the text does not definitively answer these and many other similar and important questions. Instead, courts handle these questions by the judicially devised doctrines governing "time, place, and manner" regulations of speech, press, and assembly. ${ }^{11}$ These doctrines are constitutional constructions that are nowhere in the text, but are nevertheless a good way to put into effect what the text does say.

This is not to say that, when the information provided by interpretation has run out, all decision rules have run out. We could adopt a decision rule that, where a term is vague, it is given its narrowest meaning. Or, in constitutional cases, we could say that, whenever the text is vague, legislatures have a free choice in borderline cases and cannot be second-guessed by judges. But such decision rules are rules of construction, not rules of interpretation. They are rules that apply when the information conveyed by the text itself is insufficient to decide an issue, but the issue still must somehow be decided. They are not found in the semantic content of the written Constitution.

According to the distinction between interpretation and construction, then, originalism is a method of constitutional interpretation that identifies the meaning of the text as its public meaning at the time of its enactment. The text of the Constitution may say a lot, but it does not say everything one needs to know to resolve all possible cases and controversies. Originalism is not a theory of what to do when original meaning runs out. This is not a bug; it is a feature. Were a constitution too specific, its original meaning probably would become outdated

9. See, e.g., Kovacs v. Cooper, 336 U.S. 77 (1949) (holding that restrictions on sound trucks did not violate the First Amendment).

10. See, e.g., Forsyth Cnty. v. Nationalist Movement, 505 U.S. 123 (1992) (holding that an ordinance requiring different fees for different types of demonstrations violated the First Amendment).

11. See, e.g., Perry Educ. Ass'n v. Perry Local Educators' Ass'n, 460 U.S. 37, 45 (1983); U.S. Postal Serv. V. Council of Greenburgh, 453 U.S. 114, 132 (1981). 
very quickly. A constitution with a degree of vagueness delegates some decisions of application to the judgment of future actors, provided these decisions do not conflict with the information that is provided by the text.

Originalists will not all agree about how to engage in constitutional construction. Part of this disagreement will stem from their differing normative reasons for favoring originalist interpretation. Originalists who ground their commitment to originalism in notions of popular sovereignty can be expected to favor principles of construction that reflect this normative commitment. Likewise, those who favor originalism as a means to protect the background rights retained by the people will likely favor rules of construction that are rights protective. Unless there is something in the text that favors one construction over the other, it is not originalism that is doing the work when one selects a theory of construction to employ when original meaning runs out, but one's underlying normative commitments.

So, just as originalists need a normative theory to explain why we today should adhere to the original meaning of the Constitution, they also need a normative theory for how to construe a constitution when its meaning runs out. There is no escaping this. If you think the courts should defer to the legislature when a particular clause is vague, you need a normative argument for this principle of construction. The same goes for adopting a "presumption of liberty" that places the burden on the government to justify its restrictions on liberty as necessary and proper. This too is a constitutional construction. ${ }^{12}$

Of course, nonoriginalists face all the same questions when they assert that we should follow the contemporary meaning of the text, or Supreme Court decisions that supersede the text. ${ }^{13}$ To the extent they are offering a method of interpretation, they are making empirical claims about the semantic meaning of the text of the Constitution today, or the semantic meaning of what the Supreme Court has said in its opinions. They then need a normative reason for following this meaning and employing it to decide constitutional controversies, or disregarding the semantic meaning in favor of some other.

12. See BARNETT, supra note 1.

13 See, e.g., DAVID A. STRAuSs, THE LIVING CONSTITUTION (2010) (defending a common-law theory of "living" constitutional law). 
Should nonoriginalists claim, however, that all interpretation is a matter of normative choice, they are actually spurning the information embedded in the text in favor of meanings wholly supplied or constructed by the purported interpreter. For such nonoriginalists, everything is construction. For them, there is no empirical "there" there.

With this as background let me now turn to what John McGinnis and Mike Rappaport have called "original methods originalism." 14 There is much in their approach with which I agree. First, we agree that the meaning of constitutional language should be ascertained by interpretive methods in existence at the time the language was enacted..$^{15}$ Second, we agree that most cases of ambiguity can be resolved in this way. ${ }^{16}$ But we disagree about the problem of vague language.

Whereas McGinnis and Rappaport treat ambiguity and vagueness together as essentially the same problem, to be decided by the weight of the evidence, ${ }^{17}$ I consider these to be two distinguishable linguistic problems. With ambiguity, historical context usually allows us to identify which of multiple competing senses of a term is its most likely public meaning. With vagueness, however, semantic meaning truly does run out after all genuinely interpretive methods are exhausted. More historical evidence will not tell you whether the thermal imaging of a house is or is not a search. Of course, when originalist methodology is properly applied, some supposedly vague provisions in the text are often much less vague than they are made out to be. But residual vagueness inevitably remains and is only concealed by treating rules of construction-such as, "defer to the legislature in cases of vagueness" - as though they are rules of interpretation.

Perhaps there is a distinctively "originalist" theory of construction by which we follow what the founding generation would have done when confronted with problems of applying vague language to particular cases. Unlike ascertaining original semantic meaning, however, ascertaining "what the framers would have done" is a counterfactual, not a factual or historical inquiry.

14. John O. McGinnis \& Michael B. Rappaport, Original Methods Originalism: A New Theory of Interpretation and the Case Against Construction, 103 NW. U. L. REV. 751, 751 (2009).

15. See id. at 773 .

16. Id.

17. Id. at 774 passim. 
Indeed, this shows that, when engaged in such a thought experiment about "framers' intent," one is no longer engaged in empirical inquiry. Because thermal imaging did not exist at the time of the founding, there is no historical fact of the matter to be discovered. All we can do is speculate about something that never happened. Therefore, one is no longer engaged in interpretation, strictly speaking.

If construction is inevitable because the information contained in the text runs out before we have enough information resolve a case or controversy, then originalists need to debate not only the appropriate approach to constitutional interpretation but also the appropriate approach to construction. Some may wish to avoid this normative discussion, but cases still need to be decided. Others will smuggle their normative preferences into their constitutional analysis by adopting some principles of construction over others without fully defending their choices or acknowledging that some defense is necessary. Or they may assume or imply that these principles of construction are required by originalism itself.

Originalists only confuse themselves and their audience, however, if they try to make more of originalist constitutional interpretation than the text will bear by collapsing the distinction between interpretation and construction-two necessary and intertwined, but nonetheless different, activities. 